\title{
Martyna Kawińska
}

Uniwersytet Kardynała Stefana Wyszyńskiego w Warszawie

\section{AKTYWNOŚć EDUKACYJNA SENIORÓW A KONCEPCJA AKTYWNEGO STARZENIA SIE}

\begin{abstract}
Educational activity of seniors and the concept of active aging. The article is an attempt to answer the question of how to manage inevitable old age in a changing reality. The aim of the presented study is to present the concept of active aging and to define the role of education in this process. The presented considerations are of theoretical nature, deepened by the literature of the subject and statistical studies. The main conclusion from the study is the belief that education is not only an opportunity, but a guarantee of active aging, provided that it will be implemented in a systemic and long-lasting way.

Aktywność edukacyjna seniorów a koncepcja aktywnego starzenia się. Artykuł jest próbą odpowiedzi na pytanie, jak w zmieniającej się rzeczywistości zarządzać nieuniknioną starością. Celem prezentowanego opracowania jest przybliżenie koncepcji aktywnego starzenia się i określenia roli edukacji w tym procesie. Przedstawione rozważania mają charakter teoretyczny, pogłębiony o literaturę przedmiotu i opracowania statystyczne. Główny wniosek płynący z opracowania to przekonanie, że edukacja jest nie tylko szansą, ale gwarantem aktywnego starzenia się, pod warunkiem że będzie realizowana w sposób systemowy i długotrwały.
\end{abstract}

Keywords old age, seniors, educational activity of seniors, education, aging starość, seniorzy, aktywność edukacyjna seniorów, edukacja, starzenie się

Tradycyjnie ukształtowane wartości, doświadczenie życiowe, społeczne i zawodowe stanowią fundament życia człowieka. W ponowoczesnym świecie, doświadczamy jednak tak wiele zmian, że wymuszają one podejmowania intensywnej aktualizacji własnej tożsamości, co może prowadzić do niepewności, obaw, zagubienia czy zwątpienia. Takie 
nowe doświadczenia mogą być szczególnie trudne dla człowieka starszego, który staje przed wyzwaniami, które nigdy wcześniej nie były jego udziałem. Wzorce starzenia się i przeżywania starości odbiegają od tych utrwalonych w naszej świadomości, przez co doświadczenie własnej starości może być niezmiernie trudne. Z jednej strony wydłuża się przeciętne dalsze trwanie życia człowieka, na skutek czego w naturalny sposób wydłuża się okres przeżywania starości. $Z$ drugiej strony nabyte doświadczenia całożyciowe, będą generować jakość starzenia się. Pojawia się więc naturalne pytanie, jak w tej zmieniającej się rzeczywistością zarządzać nieuniknioną starością.

Odpowiedz na tak postawione pytanie można znaleźć w szeroko rozumianej edukacji, która przygotuje jednostkę i społeczeństwo do procesu starzenia się. Nie chodzi tylko o to, aby mieć świadomość zachodzących w życiu zmian, ale także umieć się do tych zmian przystosować, zapewniając sobie jak najdłuższą samodzielność i niezależność. W ten sposób edukacja wpisuje się w koncepcję aktywnego starzenia się, a jej rola w poszczególnych fazach cyklu życia człowieka, nabiera co raz większego znaczenia. W koncepcji aktywnego starzenia się uczenie się, postrzegane jest jako proces całożyciowy i ciągły, obejmujący wszystkie obszary życia ludzkiego. W takim wymiarze edukacja realizowana jest $\mathrm{w}$ systemie formalnym, nieformalnym oraz pozaformalnym. Każdy z tych systemów ma na celu nauczać, tak aby wspólnie żyć i uczestniczyć w życiu społecznym, aby wiedzieć, jak w tym życiu uczestniczyć i czerpać z niego jak najwięcej korzyści dla siebie i społeczeństwa i jak najbardziej wartościowym dla siebie i dla innych.

Celem prezentowanego opracowania jest przybliżenie koncepcji aktywnego starzenia się i określenia roli edukacji w tym procesie. Przedstawione rozważania mają charakter teoretyczny, pogłębiony o literaturę przedmiotu i opracowania statystyczne. Główny wniosek płynący z opracowania to przekonanie, że edukacja jest nie tylko szansą, ale gwarantem aktywnego starzenia się, pod warunkiem, że będzie realizowana w sposób systemowy i długotrwały.

\section{STAROŚĆ I STARZENIE SIĘ LUDNOŚCI}

Pogłębiający się proces starzenia się ludności jest jednym z ważniejszych problemów współczesnej Europy, a co za tym idzie także społeczeństwa naszego kraju. Polska już dawno przekroczyła próg demograficznej starości ${ }^{1}$, a w nadchodzących latach prognozowany jest systematyczny wzrost odsetka osób w wieku 60 lat i więcej. Wyniki prognozy ludności w perspektywie do 2050 roku wskazują na istotną zmianę w strukturze wieku populacji. Przy przewidywanym spadku liczby ludności $04,5 \mathrm{mln}$, oczekiwany jest wzrost liczby osób starszych, którzy pod koniec prognozy będą stanowić ponad 40 proc. całego społeczeństwa. Równocześnie od 2026 roku będziemy obserwować dynamiczny wzrost odsetka osób w wieku 80 lat i więcej, który w okresie od 2025 do 2040 roku podwoi się i wyniesie 3,4 mln osób.

1 Według ONZ oznacza on 7-procentowy udział osób w wieku 65 lat i więcej w ogólnej strukturze ludności. 
Tab. 1. Odsetek osób w wieku 60 lat i więcej w całej populacji

\begin{tabular}{ccccc} 
Kategoria & \multicolumn{4}{c}{ Rok prognozy } \\
& $\mathbf{2 0 2 0}$ & $\mathbf{2 0 3 0}$ & $\mathbf{2 0 4 0}$ & $\mathbf{2 0 5 0}$ \\
\hline 60 lat i więcej & 25,9 & 29,0 & 34,4 & 40,4 \\
\hline 80 lat i więcej & 4,4 & 5,9 & 9,5 & 10,4 \\
\hline Miasta & 28,1 & 31,0 & 36,3 & 42,3 \\
\hline Wieś & 22,5 & 26,3 & 31,6 & 37,8 \\
\hline Kobiety & 29,1 & 32,4 & 37,7 & 43,4 \\
\hline Mężczyźni & 22,5 & 25,2 & 30,9 & 37,3 \\
\hline
\end{tabular}

Źródło: zestawienie własne na podstawie Informacji o sytuacji osób starszych w Polsce za rok 2015, MRPiPS 2016, s. 18.

Wśród populacji seniorów dominującą grupą są kobiety (ponad 61 proc.), a na 100 mężczyzn przypada ich 160, co jest konsekwencją nadumieralności mężczyzn i zróżnicowanej wartości przeciętnego dalszego trwania życia. Przewaga liczebna kobiet zwiększa się w kolejnych starszych kategoriach wiekowych i dla populacji osób w wieku 65-69 lat stanowią one 56 proc. zbiorowości, a współczynnik feminizacji wynosi 126. $\mathrm{W}$ miastach osoby starsze to prawie 16 proc. populacji, dla porównania na terenach wiejskich zamieszkuje ich niewiele ponad 13 proc. W odniesieniu do wskazywanej prognozy w populacji seniorów nadal będziemy obserwować liczebną przewagę kobiet oraz częstsze zamieszkiwanie w mieście niż na obszarach wiejskich ${ }^{2}$. Zmiany w natężeniu zgonów są przyczyną wydłużania się życia. W 2014 roku przeciętne dalsze trwanie życia kobiety w wieku 60 lat wyniosło 24,3 lata, a mężczyzny 19,2 - w porównaniu z 1991 rokiem było to o 4-5 lat więcej. Oprócz wydłużania się trwania życia istotne znaczenie odgrywa również liczba lat w zdrowiu, czyli życia bez niepełnosprawności, która dla mężczyzny w wieku 65 lat wynosi 7,5 roku, a dla kobiet w tym samym wieku 87, $1^{3}$.

Zwiększająca się populacja osób starszych charakteryzuje się równocześnie bardzo silnym zróżnicowaniem, a ludzie starzy są przedmiotem ciągłych i złożonych badań naukowych. Przy analizie starości i starzenia się będziemy więc mieć do czynienia z pluralizmem definicyjnym, metodologicznym i teoretycznym. Już sama próba zdefiniowania starości i starzenia się wskazuje na wielość kryteriów, które należałoby uwzględnić przy operacjonalizacji tych pojęć. Na potrzeby podjętej analizy ważniejsze od analizy zachowań i stanów poszczególnych jednostek przeżywających etapy starości wydaje się rozpoznanie uwarunkowań aktywności osób starszych i ich uczestnictwa w życiu społecznym. Nie ulega również wątpliwości, że wzrost populacji osób starszych wymusza konieczność podejmowania konkretnych systemowych działań, które przyczynią się

2 GUS 2014, Sytuacja demograficzna osób starszych i konsekwencje starzenia sięludności Polski w świetle prognozy na lata 2014-2050, Warszawa 2014, s. 33-34.

3 MRPiPS 2016, Informacja o sytuacji osób starszych $w$ Polsce za rok 2015, s. 17. 
do wzrostu świadomości i większej odpowiedzialności za proces starzenia się i doświadczenie starości.

W ramach złożonych postulatów wskazuje się na konieczność rozwoju wśród dorosłych obywateli orientacji na przyszłość, poprzez propagowanie koncepcji zwiększonej odpowiedzialności za siebie w okresie starości. W praktyce oznacza to ponoszenie odpowiedzialności za swój stan zdrowia, umysłu i duszy, czego wyrazem będzie określony styl życia i zachowania prozdrowotne. W schemat ten wpisuje się wzrost świadomości seniorów w kwestii praw własnych - socjalnych, zawodowych i edukacyjnych, będących świadectwem traktowania osób starszych jako zasobu cennego kapitału, prospołecznych wartości i umiejętności współpracy międzypokoleniowej ${ }^{4}$. Daje więc to podstawy do większego zaangażowania się w promocję pomyślnego i aktywnego starzenia się poprzez rozwój edukacji społecznej.

\section{EDUKACJA Do STAROŚCI I W STAROŚCI -}

\section{AKTUALIZACJA WIEDZY, KWALIFIKACJI I UMIEJĘTNOŚCI}

Jakość życia osób starszych określana jest determinantami wewnętrznymi i zewnętrznymi. Wśród zasobów zewnętrznych największe znaczenie przypisuje się sieciom wsparcia społecznego, składającym się z najbliższej rodziny, znajomych czy sąsiadów. Istotną rolę odgrywa również organizacja środowiska lokalnego i jego otwartość na seniorów. Właściwie funkcjonująca sieć kontaktów społecznych sprzyja rozwojowi grup samopomocy oraz konkretnych usług zabezpieczających potrzeby seniorów. Analizując zewnętrzne uwarunkowania, należy także pamiętać o czynnikach finansowych, odpowiedzialnych za sytuację ekonomiczno-bytową seniorów, oraz otoczeniu fizycznym i usługach ochrony zdrowia ${ }^{5}$.

Drugą grupę czynników stanowią zasoby wewnętrzne (indywidualne), które powinny być kształtowane przez cały okres życia człowieka. Czynniki wewnętrze będą więc zależne od rodzaju cech osobowościowych jednostki i prowadzonego przez nią stylu życia. W tym przypadku stosowne znaczenie przypisuje się wiedzy, umiejętnościom, doświadczeniu, gotowości edukacyjnej, a nawet relacjom społecznym i zdrowiu. Wszystko to składa się na zespół czynników, na które osoba starsza może mieć bezpośredni wpływ, a jest on tym większy, im bardziej systematycznie uczestniczyła ona w złożonym procesie edukacyjnym.

Przyjmuje się, że edukacja może ułatwić seniorom przystosowanie się do zmian społecznych, kulturowych czy gospodarczych, które towarzyszą współczesnym społeczeństwom. Ważne jest, aby rozpoczęła się we wczesnym okresie życia, dzięki czemu „spotkanie ze starością” będzie mniej dotkliwe. Szczególne znaczenie edukacji w tym

4 P. Szukalski, Starzenie się ludności - wyzwanie XXI wieku, w: P. Szukalski, Z. Szweda-Lewandowska, Elementy gerontologii społecznej, Skrypt dla studentów Podyplomowego Studium Gerontologii Społecznej Ut, Łódź 2014, s. 19.

5 A. Richert-Kaźmierska, M. Forkiewicz, Kształcenie osób starszych w koncepcji aktywnego starzenia się, „Studia Ekonomiczne” (2013) 131, s. 128. 
obszarze należałoby przypisać wiekowi średniemu, w którym pojawiają się pierwsze oznaki starzenia się organizmu. Jest to zazwyczaj czas pogodzenia się ze stopniowym odchodzeniem z domu i usamodzielnianiem się dzieci, a także czas opieki nad starzejącymi się rodzicami. Pojawia się więc konieczność akceptacji przeciwstawnych tendencji wynikających ze zmian biologicznych, fizycznych, psychicznych czy ekonomicznych. Może więc równocześnie występować młodość i starość, aktywność i bierność, integracja i odosobnienie, przy czym akceptacja tych tendencji będzie oznaką mądrości i dojrzałości do przeżywanych zmian. W wieku średnim powinniśmy utrwalać i rozwijać wcześniej nabyte kompetencje oraz pozyskiwać nowe, które umożliwią zachowanie równowagi między przeszłością, teraźniejszością i przyszłością, co będzie świadectwem realizacji określonych zadań rozwojowych ${ }^{6}$.

Mając na uwadze powyższe rozważania, można przyjąć, że przygotowanie do starości będzie polegać na utrzymywaniu życiowej aktywności, tak długo jak będzie to możliwe ze względów zdrowotnych, przy równoczesnym podtrzymywaniu wcześniejszych zainteresowań i odkrywaniu nowych obszarów, w ramach kontaktów rodzinnych, towarzyskich i społecznych. Takie działania będą służyć ograniczaniu izolacji społecznej seniorów, a nade wszystko ich osamotnienia, ale wymaga to dużej świadomości własnych potrzeb i przyzwyczajeń oraz rozwoju umiejętności przystosowywania się do zmieniających się warunków ${ }^{7}$.

Edukacja jako system uczenia się i nabywania kompetencji ma tak zróżnicowane obszary oddziaływania, że może być realizowana zarówno w instytucjach edukacyjnych, jak i poza nimi, np. w środowisku rodzinnym lub towarzyskim ${ }^{8}$. Osoby starsze korzystają przede wszystkim z nieformalnych i pozaformalnych form kształcenia, realizowanych poza instytucjonalnym systemem edukacyjnym. W procesie edukacji seniorów duże znaczenie przypisuje się więc działaniom praktycznym, których realizacja ma miejsce często podczas rozmów i spotkań towarzyskich, gdzie wymiana informacji jest źródłem wiedzy, a utrzymywanie kontaktów wpływa na postrzeganie otaczającego nas świata. To uczenie się wpływa na lepsze rozumienia świata i samego siebie ${ }^{9}$, co przekłada się na wyższą jakość życia. Postęp cywilizacyjny i dynamiczny rozwój społeczny wymuszają na człowieku permanentne uczenie się, które definiowane jest jako trwający przez całe życie proces nabywania wiedzy, kwalifikacji i umiejętności. Ta forma kształcenia, obok edukacji formalnej i nieformalnej, odgrywa szczególną rolę w procesie przygotowywania do starości, a jej zaletą jest duża swoboda w doborze narzędzi i metod, odpowiedzialnych za zmianę postrzegania starości i roli człowieka starszego w społeczeństwie ${ }^{10}$.

${ }^{6}$ L. Miś, Ery i fazy rozwoju w życiu człowieka dorosłego w ujęciu Daniela J. Levinsona, w: Duchowy rozwój człowieka, red. P. Socha, Kraków 2000, s. 55-56.

7 A. Kamiński, Funkcje pedagogiki społecznej, Warszawa1974, s. 369.

8 J. Kargul, Obszary pozaformalnej i nieformalnej edukacji dorosłych. Przesłanki do budowy teorii edukacji całożyciowej, Wrocław 2005, s. 46.

9 A. Roguska, Edukacja permanentna osób dorosłych $w$ starości, w: Edukacja permanentna dorosłych $w$ dobie przemian, red. T. Zacharuk, B. Boczukowa, Kielce 2009, s. 77.

10 J. Halicki, Zaspokajanie potrzeb edukacyjnych jako czynnik aktywnego starzenia się, w: Aktywne starzenie się. Przeciwdziałanie barierom, red. P. Szukalski, B. Szatur-Jaworska, Łódź 2013, s. 143. 
Charakterystyczną cechą populacji osób starszych jest ich duże zróżnicowanie pod względem poziomu wykształcenia, sytuacji rodzinnej czy ekonomicznej, przez co ich potrzeby edukacyjne będą również zróżnicowane. Ma to również związek z doświadczeniem życiowym, które zdobywali przez całe życie, z przyzwyczajeniami oraz oczekiwaniami względem zbliżającej się bądź już przeżywanej starości. W okresie późnej dorosłości i wczesnej starości następuje ograniczenie okazji do poszerzania swoich kompetencji, przez co może wzmagać się poczucie odrzucenia, izolacji i bezużyteczności. Dlatego bardzo ważne jest tworzenie oferty edukacyjnej dla seniorów, która uwzględniałaby ich zasoby i indywidualne potrzeby. Wskazuje się więc na konieczność projektowania działań edukacyjnych dla osób starszych, które uwzględniałyby zmiany zachodzące w ich życiu ${ }^{11}$.

Osoby starsze w edukacji coraz częściej odnajdują nie tylko rozrywkę intelektualną oraz kulturalną, ale także trening umysłowy, będący drogą do stałego rozwoju oraz utrzymania jak najdłuższej samodzielności i niezależności ${ }^{12}$. W związku z tym coraz większego znaczenia nabiera koncepcja life long learning - uczenia się przez całe życie, według której edukacja to otwarty i niekończący się rozwój ${ }^{13}$. W takim ujęciu realizowana jest przez wszelkie wskazywane wcześniej formy nauki, które podejmowane są przez całe życie, w celu zgłębiania wiedzy, rozwoju umiejętności i kompetencji w kontekście indywidualnym i społecznym. Człowiek poprzez całożyciowe uczenie się ma szansę stać się źródłem konkurencyjności nie tylko na rynku pracy, ale także w sferze życia społecznego, rodzinnego i towarzyskiego. Promowanie koncepcji life long learning służy więc wspieraniu aktywnego i produktywnego starzenia się.

\section{AKTYWNE STARZENIE SIĘ $W$ KONTEKŚCIE PRZYGOTOWANIA I PRZYSTOSOWANIA SIĘ DO STAROŚCI}

Problematyka podejmowania aktywności przez osoby starsze wpisuje się w koncepcję pomyślnego starzenia się (sucessful aging), która określa trzy podstawowe kryteria, uprawniające do uznania, że właśnie z takim rodzajem starzenia się mamy do czynienia. Za najważniejsze wyznaczniki uznaje się więc niski poziom niepełnosprawności, wysoki stopień samodzielnego funkcjonowania fizycznego i umysłowego oraz aktywne uczestnictwo w życiu ${ }^{14}$. Przyjęta koncepcja zakłada wykorzystanie wszystkich dostępnych zasobów człowieka do optymalnego przygotowania do procesu starzenia się. Starzenie się jest naturalnym procesem i wartościowym doświadczeniem zdecydowanej większości osób. Sposób przeżywania starości będzie zależeć od czynników zewnętrznych

11 J. A. Sienkiewicz-Wilowska, Społeczne aspekty bycia seniorem a rozwój osób w okresie późnej dorosłości, w: Edukacja osób starszych. Uwarunkowania - trendy - metody, Warszawa 2013, s. 35-36.

12 A. Fabiś, Edukacja - odpowiedź na wymagania współczesności, „Edukacja Dorosłych” (2006) nr 1-2, s. 34 .

13 E. Kowalska-Dubas, Lifelong learning - aktualizowanie wiedzy, umiejętności i kwalifikacji, w: Rozwiązania sprzyjające aktywnemu starzeniu się w wybranych krajach Unii Europejskiej. Raport konco$w y$, red. E. Kryńska, P. Szukalski, Łódź 2013, s. 59-70.

14 J. Halicki, Zaspokajanie potrzeb edukacyjnych, dz. cyt., s. 145. 
i wewnętrznych, wzajemnie się uzupełniających. Po stronie determinant wewnętrznych znaczącą rolę będą odgrywać wrodzone predyspozycje psychiczne, odpowiedzialne za stan woli i umysłu, oraz indywidualne cechy człowieka. Czynniki zewnętrze zależą od środowiska życia człowieka, w tym m.in. miejsca zamieszkania, warunków mieszkaniowych, sytuacji zawodowej i rodzinnej, pozycji społecznej, dostępności do usług medycznych i ich jakości ${ }^{15}$.

Obecnie także UE, odnosząc się do problematyki starzenia się, rozwija promocję aktywnego starzenia, które definiowane jest jako narzędzie przeciwdziałania starzeniu się ludności, poprzez oddziaływanie na jednostki i uświadamianie im konieczności przygotowania do długiej starości indywidualnej. Przygotowanie to obejmuje pracę zawodową, zdrowie, edukację, aktywność społeczną czy zabezpieczenie odpowiedniego poziomu życia ${ }^{16}$. Głównym założeniem promowanej koncepcji aktywnego starzenia się jest przekonanie o konieczności zachowania jak najdłuższej społecznej użyteczności jednostki, która odnosi się do wszystkich obszarów aktywności jednostki z wyłączeniem prac domowych, opieki i pomocy członkom rodziny i przyjaciołom ${ }^{17}$.

W kontekście aktywnego starzenia zwraca się uwagę na życie człowieka jako proces, w którym jednostka powinna odpowiednio przygotowywać się do starości. Wszelkie formy aktywności warunkują zaspokajanie potrzeb człowieka, pełnienie określonych ról społecznych, funkcjonowanie w grupie i społeczeństwie. Brak aktywności w tym wypadku może powodować utratę akceptacji otoczenia, aż po izolację i wykluczenie społeczne, a w konsekwencji osamotnienie ${ }^{18}$. Teoria aktywności pozostaje więc w naturalny sposób w opozycji do teorii wycofania się, zgodnie z którą osoby starsze wraz $\mathrm{z}$ wiekiem rezygnują z wcześniejszych form aktywności. Warunkiem udanej i satysfakcjonującej starości może być długotrwała realizacja wszelkich form aktywności, która przełoży się na jakość życia seniorów i ich samoocenę. Wszelkie przejawy aktywności można więc uznać za bardzo ważną potrzebę psychiczną i fizyczną w każdym wieku, a brak wzorców aktywnego spędzania czasu wolnego jest konsekwencją powszechnego i biernego stylu życia ${ }^{19}$.

Nabycie wzorców aktywnego starzenia się warunkowane jest odpowiednimi cechami człowieka, które będą pełnić ważne funkcje poznawcze w życiu codziennym. Należą do nich: odwaga, optymizm, uczciwość, nadzieja, wnikliwość, umiejętność angażowania się i zmagania z trudnościami. To właśnie one będą odpowiedzialne za zwiększanie dobrostanu człowieka, nawet przy pogarszaniu się stanu zdrowia czy niekorzystnych zmianach zachodzących w życiu jednostki. Pozytywne starzenie się, będące filarem

15 D. R. Hill, Pozytywne starzenie się. Młodzi duchem w jesieni życia, przeł. M. Lipa, Warszawa 2009, s. 42.

16 P. Szukalski, Przygotowanie do starości jako zadanie dla jednostek i zbiorowości, w: Przygotowanie do starości. Polacy wobec starzenia się, red. P. Szukalski, Warszawa 2009, s. 39-55.

17 P. Szukalski, Starzenie się ludności..., dz. cyt., s. 21.

18 Aktywność społeczna i edukacyjna w fazie starości, w: Podstawy gerontologii społecznej, red. B. SzaturJaworska, P. Błędowski, M. Dzięgielewska, Warszawa 2006, s. 161.

19 J. Halik, Starzenie się społeczeństw jako proces demograficzny, w: Starzy ludzie w Polsce. Społeczne i zdrowotne skutki starzenia się społecznego, red. J. Halik, Warszawa 2002, s. 18. 
aktywnego starzenia się, jest określonym stanem umysłu i określoną strategią działa$n^{2}{ }^{20}$. Doświadczanie starości i kształtowanie tego procesu w sposób aktywny wymaga wewnętrznej dyscypliny i pracy jednostkowej, polegającej na wykorzystaniu motywacji i posiadanych zasobów do akceptacji zmian związanych z wiekiem. Celowe wydaje się także dokonywanie wyborów określonego stylu życia według możliwości fizycznych i psychicznych człowieka, tak aby doświadczać satysfakcji z jakości własnego życia. Znacząca jest także umiejętność dostrzegania pozytywnych aspektów własnego życia, poprzez zachowanie dystansu do trudności będących konsekwencją starzenia się organizmu. Konieczna jest również technika adaptacji do zmieniających się uwarunkowań i umiejętność korzystania z różnych form wsparcia w sytuacji, kiedy następuje ograniczanie samodzielności ${ }^{21}$.

W toku prac badawczych koncepcja aktywnego starzenia się rozprzestrzeniła się na wszystkie aspekty życia człowieka i zaczęto ją utożsamiać z produktywnością społeczną, wyrażaną jako zdolności ludzi do produktywnego życia w społeczeństwie i w gospodarce, podczas całego procesu starzenia się. W takim ujęciu osoby starsze powinny mieć możliwość wyborów co do spędzania czasu wolnego czy dynamiki aktywności zawodowej i społecznej. Natomiast kiedy możliwości wyboru są ograniczane stanem zdrowia, barierami architektonicznymi, urbanistycznymi, niedostosowaniem miejsca pracy, wówczas powinny zadziałać systemowe rozwiązania eliminujące takie ograniczenia. Takie podejście wpisuje się w wielowymiarową koncepcję aktywnego starzenia się, autorstwa Światowej Organizacji Zdrowia, która zwraca szczególną uwagę na konieczność optymalizacji złożonych działań, wpływających na poprawę jakości życia osób starszych. Jest więc wskazanie na zdrowie, uczestnictwo i bezpieczeństwo, dzięki któremu ludzie powinni uczyć się przez całe życie, przechodzić na emeryturę stopniowo i w późniejszym wieku, podtrzymywać podjętą wcześniej aktywność. Służyć temu mają dobra kondycja zdrowotna i wysoka sprawność fizyczna, które umożliwiają pełnienie ról rodzinnych, realizację pasji życiowych i działań twórczych, uprawianie sportu i turystyki, uczestnictwo w życiu społeczności lokalnej, rozwój wolontariatu ${ }^{22}$.

Oprócz samej koncepcji Światowa Organizacja Zdrowia określiła najważniejsze determinanty aktywnego starzenia się, wśród których za najważniejsze uznała płeć i uwarunkowania kulturowe. Wzorzec starzenia się będzie określony przez normy, wartości i obyczaje, które obowiązują w środowisku rodzinnym i społeczności lokalnej przy równoczesnej akceptacji społecznej poszczególnych faz w życiu człowieka, a przede wszystkim ostatniej fazy związanej ze starością i starzeniem się. Za drugi ważny czynnik odpowiedzialny za starzenie się uznano płeć, która wyznacza role męskie i żeńskie w tym procesie. Kobiety częściej narażone są na ubóstwo i wykluczenie społeczne w fazie starości, na skutek większego zaangażowania w prowadzenie gospodarstwa domowego. Często wiąże się to z koniecznością sprawowania opieki nad członkami rodziny, w tym dzieci, wnucząt, niesamodzielnych bądź niepełnosprawnych krewnych. Mężczyźni natomiast

20 R. Konieczna-Woźniak, Uczenie się jako strategia pozytywnego starzenia się, ,Rocznik Andragogiczny” 20 (2013), s. 192.

${ }^{21}$ D. R. Hill, Pozytywne starzenie się..., dz. cyt., s. 16.

22 Ł. Jurek, Aktywne starzenie się jako paradygmat w polityce społecznej, „Polityka Społeczna” (2012) 3, s. 9. 
bardziej narażeni są na choroby i ryzyka zawodowe oraz zły stan zdrowia będący konsekwencją stosowania używek czy braku odpowiedniej profilaktyki zdrowia ${ }^{23}$.

Rys. 1. Determinanty aktywnego starzenia się według Światowej Organizacji Zdrowia

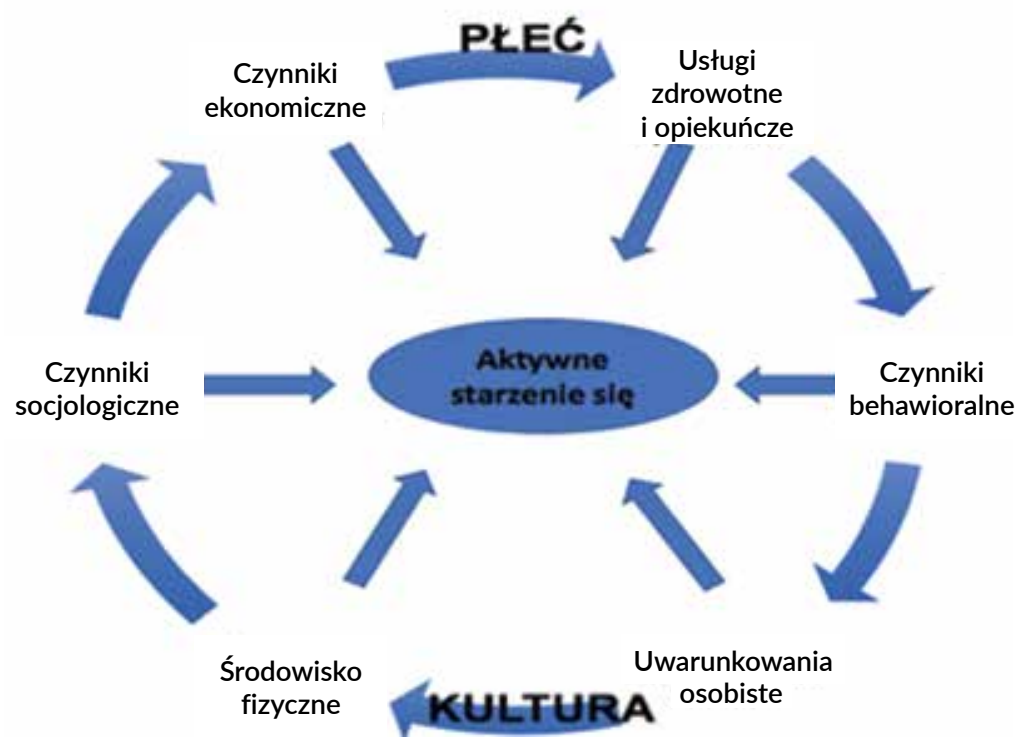

Źródło: zestawienie własne na podstawie WHO (2002), Active ageing: a policy framework, Geneva, World Health Organization, s. 19.

Aktywne starzenie się jest więc wielowymiarowym procesem, za który odpowiadają szczegółowe działania mające na celu podniesienie jakości życia osób starszych, a to przekłada się na ograniczenie wydatków publicznych, związanych ze świadczeniami emerytalnymi, usługami zdrowotnymi i opiekuńczymi. Docelowo należy również oczekiwać ograniczenia obciążenia osobami starszymi. Aby osiągnąć takie korzyści, aktywne starzenie powinno uwzględniać wszystkie działania, aktywizujące seniorów, a głównym jego zadaniem powinno być przeciwdziałanie wykluczeniu społecznemu tej grupy. Oznacza to konieczność edukacji do starości, która powinna mieć miejsce w każdej fazie życia człowieka, i edukacji w starości, która ułatwi pokonywanie trudności wynikających ze starzenia się organizmu. Aktywności uczymy się więc przez całe życie, po to, aby w ostatniej fazie życia aktywne starzenie mogło być konsekwencją aktywnego uczestnictwa.

${ }^{23}$ Ł. Jurek, Aktywne starzenie się jako paradygmat w polityce społecznej, dz. cyt., s. 10. 


\section{Aktywność edukacyjna osób starszych w Polsce}

Osoby starsze w Polsce charakteryzują się niskim uczestnictwem edukacyjnym, mierzonym udziałem w kształceniu formalnym i nieformalnym. Aktywność edukacyjna seniorów charakteryzuje się istotnym stopniem zróżnicowania pod względem płci, miejsca zamieszkania i wykształcenia. Niestety także wiek istotnie wpływa na poziom uczestnictwa w edukacji: im osoby starsze, tym rzadziej uczestniczą w podnoszeniu kompetencji. Wśród osób po 50 roku życia w 2011 roku ponad 67 proc. nie uczestniczyło w żadnej formie kształcenia. Najbardziej popularne wśród osób starszych kształcenie nieformalne obniżyło się z 24,5 proc. w grupie 50-54 lata do 15,6 proc. w grupie 65-69 lat. Dynamiczny spadek obserwujemy także w przypadku kształcenia pozaformalnego, które w przypadku zbiorowości osób w wieku 65-69 lat wyniosło zaledwie 2,8 proc., a wśród osób w wieku 50-54 lata odsetek ten wyniósł 17,9 proc. $^{24}$.

Tab. 2. Osoby dorosłe (w wieku 25-64 lata) uczestniczące w kształceniu i szkoleniu w Polsce w latach $2012-2016 \mathrm{w} \%$

\begin{tabular}{cccccc} 
Wyszczególnienie & $\mathbf{2 0 1 2}$ & $\mathbf{2 0 1 3}$ & $\mathbf{2 0 1 4}$ & $\mathbf{2 0 1 5}$ & $\mathbf{2 0 1 6}$ \\
\hline Polska & 4,5 & 4,3 & 4,0 & 3,5 & 3,7 \\
\hline Kobiety & 5,1 & 4,9 & 3,6 & 3,3 & 4,0 \\
\hline Mężczyźni & 3,8 & 3,8 & 4,3 & 3,8 & 3,4 \\
\hline
\end{tabular}

Źródło: GUS 2017, Kapitał ludzki w Polsce w latach 2012-2016, s. 150.

Niskie uczestnictwo edukacyjne osób starszych w Polsce jest konsekwencją bierności zaangażowania w proces edukacji całożyciowej. Analiza skali uczestnictwa w kształceniu osób w wieku 25-64 lata pokazuje, że wskaźnik uczestnictwa w tej grupie wiekowej w jakiejkolwiek formie kształcenia zmniejsza się od 2012 roku. Wyższą aktywność edukacyjną prezentują kobiety, przy czym na przestrzeni ostatnich lat $w$ tej grupie niestety także zmniejszył się odsetek uczestniczących w formach kształcenia i szkolenia. Dla porównania, odsetek dorosłych Europejczyków (EU-28) uczestniczących w kształceniu i szkoleniu w 2016 roku wyniósł 10,8 proc. i było to o 1,7 proc. więcej niż w 2011 roku. Do krajów europejskich, w których wskaźnik uczestnictwa w edukacji całożyciowej przekroczył 20 proc., zaliczmy Szwajcarię, Danię, Finlandię, Szwecję i Islandię. Na przeciwległym biegunie oprócz Polski znajdują się Rumunia, Bułgaria, Słowacja, Chorwacja i Grecja ${ }^{25}$.

24 GUS, Kształcenie dorosłych 2011, Warszawa 2013, s. 19.

25 Eurostat 2017, Adult learning statistics, Lifelong learning, 2011 and 2016, http://ec.europa.eu/eurostat/statistics-explained/index.php/File:Lifelong_learning,_2011_and_2016_( $\left.{ }^{1}\right)$ (\%25_of_the_population_aged_25_to_64_participating_in_education_and_training)_YB17.png (15.12.2017). 
Wyk. 1. Uczestnictwo osób w wieku 25-64 w kształceniu i szkoleniu w Europie w 2011 i 2016 roku

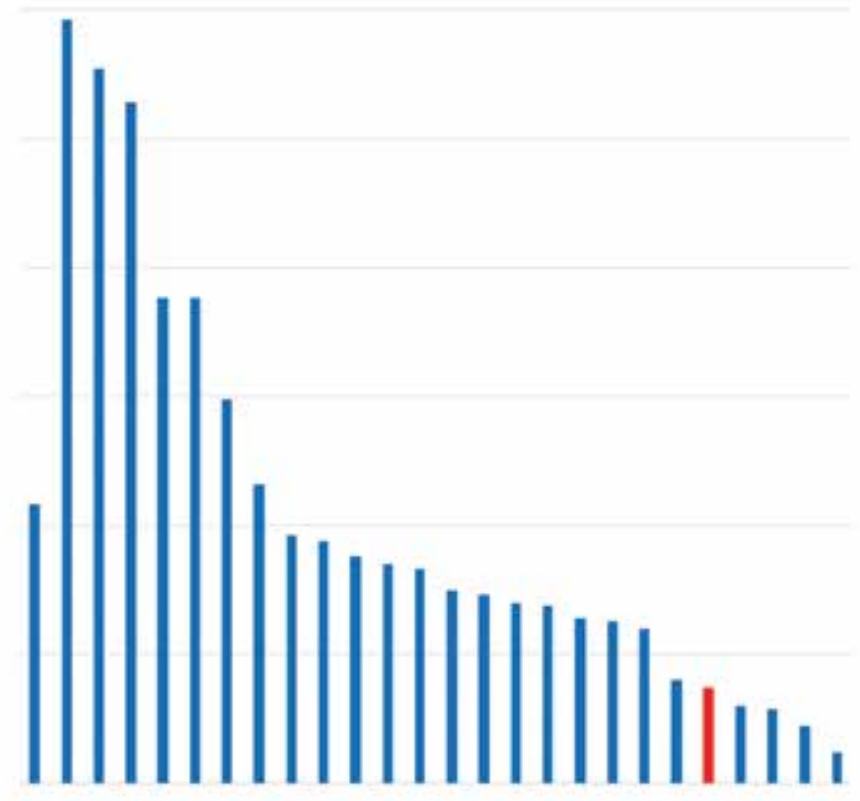

Źródło: zestawienie własne na podstawie: Eurostat 2017, Adult learning statistics, Lifelong learning, 2011 and 2016, http://ec.europa.eu/eurostat/statistics-explained/index.php/File:Lifelong_learning,_2011_and_2016_ $\left({ }^{1}\right)$-(\%25_of_the_population_aged_25_to_64_participating_in_education_and_training)_YB17.png (15.12.2017).

Do podobnych wniosków dochodzimy, korzystając z danych badania Labour Force Servey realizowanego przez Eurostat w 2015 roku, które analizuje uczestnictwo w kształceniu lub szkoleniu osób w wieku 15-74 lat. W Polsce poziom uczestnictwa osób starszych w wieku 55-74 lata w kształceniu i szkoleniu należy do jednych z najniższych wśród krajów UE i wynosi zaledwie 0,6 proc. wobec średniej 4,8 proc. w badanych krajach i 22,0 proc. w Danii - kraju będącym liderem badanej aktywności. Tak niska aktywność edukacyjna osób starszych w Polsce jest zjawiskiem trwałym i w ostatniej dekadzie poziom uczestnictwa nigdy nie przekroczył 1 proc. Zaskakująca jest również bardzo duża rozbieżność między poziomem uczestnictwa w kształceniu i szkoleniu osób na progu dorosłości, w wieku 15-19 lat a osobami starszymi, w wieku 55-74 lata. W Polsce aktywność edukacyjna osób młodych jest najwyższa wśród krajów UE i wynosi 92,5 proc. Przy 0,6 proc. aktywności osób starszych plasujemy się na ostatnim miejscu, z największą różnicą między poziomami uczestnictwa najmłodszych i najstarszych grup wiekowych objętych badaniem ${ }^{26}$.

${ }^{26}$ MRPiPS 2016, Informacja o sytuacji osób starszych w Polsce za rok 2015, dz. cyt., s. 71. 


\section{WNIOSKI}

Uczestnictwo osób starszych w projektach edukacyjnych jest jednym z obszarów koncepcji aktywnego starzenia się. Niezależnie od deficytów, które pojawiają się w cyklu życia człowieka, do starości i starzenia się możemy się przygotować. Pozytywnego i aktywnego starzenia powinniśmy się jednak uczyć, zanim się zestarzejemy, a w zasadzie najlepiej byłoby móc uczyć się przez całe życie. Do tego potrzebna jest jednak właściwa edukacja, która skierowana będzie do pojedynczych jednostek i całego społeczeństwa. Edukacja w starości ułatwia starzejącym się ludziom „dopasowanie się” do zmian zachodzących w ich życiu, w sferze osobistej, zdrowotnej i społecznej. Do tego obszaru oddziaływania edukacji należeć będzie także przyjmowanie nowych ról społecznych i przygotowanie do starości indywidualnej. Konfrontacja nabytych kompetencji z przyszłą fazą życia powinna umożliwiać częściowe zachowanie dotychczasowych obszarów aktywności i odkrywanie zupełnie nowych.

Ze względu na bardzo niską partycypację w edukacji całożyciowej w Polsce rozwój edukacji w procesie aktywnego starzenia się wymaga wielu systemowych działań. Przede wszystkim należałoby zdefiniować grupę odbiorców, która uwzględniałaby osoby starsze, młodzież, przedsiębiorców i pracodawców, instytucje społeczne i edukacyjne. Ważnym zadaniem jest także dążenie do wzrostu świadomości, że rozwój edukacji w procesie całożyciowego uczenia się będzie jedną z determinant jakości życia. Do tego potrzebna jest właściwa oferta edukacyjna, dopasowana do potrzeb i możliwości każdej grupy odbiorców. Dopiero wówczas takie długookresowe i systemowe działania mogą przyczynić się do rozwoju i umocnienia określonej kultury edukacyjnej, która umocni swoją pozycję w koncepcji aktywnego starzenia się. Proces starzenia się ludności stawia dziś nowe zadania przed systemem edukacji, zwłaszcza tej całożyciowej - oczekuje się, że rozwój tego systemu przyczyni się do lepszego przeżywania i przygotowania do starości.

\section{LITERATURA}

Duchowy rozwój człowieka, red. P. Socha, Kraków 2000.

Eurostat 2017, Adult learning statistics, Lifelong learning, 2011 and 2016, http://ec.europa.eu/ eurostat/statistics-explained/index.php/File:Lifelong_learning,_2011_and_2016_( $\left.{ }^{1}\right)_{(}(\% 25$ _of_the_ population_aged_25_to_64_participating_in_education_and_training)_YB17.png (15.12.2017).

Fabiś A., Edukacja seniorów - odpowiedź na wymagania wspótczesności, „Edukacja Dorosłych” (2006) $\mathrm{nr} 1-2$, s. 33-44.

GUS 2013, Ksztatcenie dorostych 2011, Warszawa 2013.

GUS 2014, Sytuacja demograficzna osób starszych i konsekwencje starzenia się ludności Polski w świetle prognozy na lata 2014-2050, Warszawa 2014.

Halicki J., Zaspokajanie potrzeb edukacyjnych jako czynnik aktywnego starzenia się, w: Aktywne starzenie się. Przeciwdziałanie barierom, red. P. Szukalski, B. Szatur-Jaworska, Łódź 2013, s. 142-151. 
Halik J., Starzenie się społeczeństw jako proces demograficzny, w: Starzy ludzie w Polsce. Społeczne i zdrowotne skutki starzenia się społecznego, red. J. Halik, Warszawa 2002, s. 9-27.

Hill D. R., Pozytywne starzenie się. Młodzi duchem $w$ jesieni życia, przeł. M. Lipa, Warszawa 2009.

Jurek Ł., Aktywne starzenie się jako paradygmat w polityce społecznej, „Polityka Społeczna” (2012) nr 3, s. 8-12.

Kamiński A., Funkcje pedagogiki społecznej, Warszawa1974.

Kargul J., Obszary pozaformalnej i nieformalnej edukacji dorostych. Przesłanki do budowy teorii edukacji całożyciowej, Wrocław 2005.

Konieczna-Woźniak R., Uczenie się jako strategia pozytywnego starzenia się, „Rocznik Andragogiczny” 20 (2013), s. 185-200.

Kowalska-Dubas E., Lifelong learning - aktualizowanie wiedzy, umiejętności i kwalifikacji, w: Rozwiązania sprzyjające aktywnemu starzeniu się w wybranych krajach Unii Europejskiej. Raport końcowy, red. E. Kryńska, P. Szukalski, Łódź 2013, s. 59-72.

Ministerstwo Rodziny, Pracy i Polityki Społecznej, Informacja o sytuacji osób starszych w Polsce za rok 2015, Warszawa 2016.

Miś L., Ery i fazy rozwoju w życiu człowieka dorosłego w ujęciu Daniela J. Levinsona, w: Duchowy rozwój człowieka, red. P. Socha, Kraków 2000, s. 45-60.

Podstawy gerontologii społecznej, red. B. Szatur-Jaworska, P. Błędowski, M. Dzięgielewska, Warszawa 2006.

Richert-Kaźmierska A., Forkiewicz M., Kształcenie osób starszych w koncepcji aktywnego starzenia się, w: „Studia Ekonomiczne” 131 (2013), s. 127-139.

Roguska A., Edukacja permanentna osób dorosłych w starości, w: Edukacja permanentna dorostych $w$ dobie przemian, red. T. Zacharuk, B. Boczukowa, Kielce 2009, s. 76-82.

Sienkiewicz-Wilowska J. A., Społeczne aspekty bycia seniorem a rozwój osób w okresie późnej dorosłości, w: Edukacja osób starszych. Uwarunkowania - trendy - metody, Warszawa 2013, s. $27-40$.

Szukalski P., Przygotowanie do starości jako zadanie dla jednostek i zbiorowości, w: Przygotowanie do starości. Polacy wobec starzenia się, red. P. Szukalski, Warszawa 2009, s. 39-55.

Szukalski P., Starzenie się ludności - wyzwanie XXI wieku, w: P. Szukalski, Z. Szweda-Lewandowska, Elementy gerontologii społecznej. Skrypt dla studentów Podyplomowego Studium Gerontologii Społecznej UŁ, Łódź 2014, s. 5-26. 